\title{
FACTORS AFFECTING THE SUCROSE CONTENT OF SUGARCANE: III, VARIETIES
}

\author{
M. A. Lugo-López, G. Samuels, and F. Méndez ${ }^{1}$
}

\section{INTRODUCTION}

It has been long recognized that there are significant differences among the sucrose yields of sugarcane varieties at harvesttime. All other ecological, biological, and cultural factors being constant, certain varieties normally produce more sucrose than others. The importance of superior sucrose-producing sugarcane varieties can hardly be ignored; when there are no significant differences between the mean sugar or green millable cane yields of two or more varieties, the one that can accumulate the most sucrose by harvesttime will naturally give the best returns to the grower, other factors being equal. In a 40 -ton-per-acre crop of sugarcane the monetary difference between a cane variety yielding 12 percent of available $96^{\circ}$ sugar and another yielding 13 percent may amount to $\$ 40$ or $\$ 50$ per acre, without the added expense of dealing with a heavier cane tonnage.

By far, most of the progress attained in the sugarcane industry in Puerto Rico, as well as in other sugarcane-producing areas, can be traced back to the introduction, breeding, and selection of superior cane varieties. A program of this nature cannot be limited to such factors as sucrose, tonnage, and sugar yields. Other factors must be considered also such as stooling, tillering, growth habit, vigor, quickness of closing up, covering the ground, and smothering the weeds, presence or absence of prickly hairs, shedding of dry leaves, disease resistance, and other characteristics. In spite of all these factors that the plant breeder and the field agronomist must consider, sucrose accumulation at harvesttime has top priority even at the early stages of a breeding program. The low-sucrose canes have practically disappeared. Only those with high sucrose concentrations are released to sugarcane growers for commercial trials.

The object of this paper is to evaluate the outstanding sugarcane varieties grown in Puerto Rico on the basis of their final sucrose concentrations at harvesttime.

\section{MATERIALS AND METHODS}

The data herein reported have been obtained from 41 Island-wide field experiments. Geographically these covered most of the areas where sugar-

${ }^{1}$ Associate Soil Scientist, Plant Physiologist, and Associate Agronomist, respectively, Agricultural Experiment Station, University of Puerto Rico, Río Piedras, P. R. 
cane is grown in Puerto Rico: The north, east, west, and south coasts; the Guanajibo, Lajas, and Caguas inner lowlands; and the hilly areas near San Sebastian in the west-central region, and near Cayey in eastcentral Puerto Rico. A wide variety of soils was covered ranging from the lateritic Coto clay at Isabela through alluvials such as Coloso (Arecibo, Toa Baja, Añasco, Aguada, San Germán), Toa (Cayey, Hormigueros), San Antón (Guayanilla, Aguirre), Viví (Humacao), and Vega Baja (Río Piedras); and including reddish prairie such as Santa Isabel and Machete (Aguirre and Guánica); reddish chestnut and chernozem such as Fraternidad (Guánica) and Camaguey (San Sebastián), respectively; gray-brown podzolic such as Vía (Humacao); planosols like Sabana Seca (Arecibo), and a reclaimed solonchack such as Serrano near Ponce.

From 4 to 11 varieties were compared in each test, using a randomized block lay-out in the majority of the cases, split-plot designs in others where various fertility levels were also under trial, and lattice designs in a few. A total of 109 crops were harvested from the 41 experiments considered in this study, ranging from a plant cane in a few instances to a 6-crop cycle ( 1 plant cane and 5 ratoon crops) in others, with a mean number of 3 crops for all the experiments included.

In organizing the data a number of varieties included in the original investigation was discarded because they either did not appear in a suffcient number of experiments to make comparisons worth while, or because they are rapidly disappearing from cultivation in the Island, for instance P. (Palma), Tuc. (Tucumán), and some P.O.J. (Prooefstation Oost Java) canes. Others still were discarded because they attained no commercial importance after a number of years, such as a few of the P.R. (Puerto Rico) and M. (Mayagüez) canes. Some varieties such as the C.A.'s (Central Aguirre) and some of the B. (Barbados) were included, although they appeared in only a few recent experiments because, on general inspection, they seemed to be rather promising agronomically. The data were organized according to three broad climatic regions, namely, humid, including the north, east, and west coasts, and the interior; subhumid, including the northwest zone near Isabela; and semiarid, including the Lajas Valley and the rest of the southern coast south of the main divide.

\section{PRESENTATION OF DATA AND DISCUSSION}

Table 1 gives the weighted mean sucrose yields of the 20 selected varieties included in this study. Most of the cane varieties are grown over the whole Island in a wide range of climatic, edaphic, and managerial conditions, except the C.A. (Central Aguirre) canes which are as yet limited to the semiarid irrigated southern coast and inner valleys. The best sucrose producers for Puerto Rico as a whole were M.'s 336 and 28, P.R.'s 908, 907, 
and 902, and C.A.'s 38-102 and 38-74. Of these, the P.R. 908 and the CA canes were not included in a sufficient number of trials to be considered in comparison with the other leading varieties. These varieties, as well as other promising ones from the next groups, need still more extensive testing before their performance can be correctly evaluated.

M. 336 outyielded all other varieties in the semiarid region with a mean sucrose content at harvesttime of 14.14 from 15 crops. Except for M. 28

TABLE 1.-Weighted mean sucrose yields (as available $96^{\circ}$ sugar percent cane) of 20 selected sugarcane varieties in each of 3 climatic areas and in Puerto Rico as a whole

\begin{tabular}{|c|c|c|c|c|c|}
\hline Variety & $\begin{array}{c}\text { Crops } \\
\text { (all areas) }\end{array}$ & Humid & Subhumid & Semiarid & $\begin{array}{l}\text { Puerto Rico } \\
\text { (all areas) }\end{array}$ \\
\hline & Number & & & & \\
\hline P.R. 908 & 4 & 13.66 & - & - & 13.86 \\
\hline M. 336 & 42 & 13.63 & - & 14.14 & 13.81 \\
\hline P.R. 907 & 32 & 13.14 & - & 13.47 & 13.23 \\
\hline C.A. $38-102$ & 4 & - & - & 13.16 & 13.16 \\
\hline P.R. 902 & 76 & 13.14 & 12.66 & 13.34 & 13.12 \\
\hline M. 28 & 25 & 13.68 & 12.19 & - & 13.02 \\
\hline C.A. $38-74$ & 3 & - & - & 13.01 & 13.01 \\
\hline P.R. 905 & 54 & 12.82 & 12.36 & 12.71 & 12.74 \\
\hline C.A. $38-160$ & 2 & - & - & 12.73 & 12.73 \\
\hline B. $34-104$ & 23 & 12.39 & 12.63 & 13.47 & 12.70 \\
\hline B. $37-161$ & 23 & 12.50 & 11.96 & 12.82 & 12.54 \\
\hline B.H. 10-12 & 42 & 12.19 & - & 12.60 & 12.35 \\
\hline M. 317 & 61 & 12.36 & 11.07 & 12.15 & 12.23 \\
\hline P.O.J. 2878 & 90 & 12.01 & 11.26 & 12.06 & 11.91 \\
\hline M. 275 & 73 & 11.91 & 10.72 & 11.80 & 11.83 \\
\hline P.R. 903 & 42 & 11.71 & 11.73 & 11.44 & 11.65 \\
\hline P.O.J. 2961 & 51 & 11.47 & 11.16 & 11.78 & 11.57 \\
\hline M. 341 & 5 & 11.33 & - & 10.89 & 11.07 \\
\hline F.C. 1017 & 4 & - & 11.05 & - & 11.05 \\
\hline P.R. 904 & 40 & 10.74 & - & 10.82 & 10.77 \\
\hline Weighted mean of all varieties... & 699 & 12.35 & 11.80 & 12.44 & 12.32 \\
\hline
\end{tabular}

and P.R. 908 it also produced more sucrose than any other variety in the humid region. The sucrose yield of M. 28 was 1.5-percent lower in the subhumid Isabela section than in the humid section.

The next best group of sucrose producers included P.R. 905, C.A. 38-160, B. $34-104$ and $37-161$, B.H. $10-12$, and M. 317 , with a mean range of 12.23 to 12.74 percent for the Island, irrespective of climatic influences. B. 34-104 seemed to produce better sucrose yields in southern Puerto Rico. P.R. 905 in 54 crops had a mean sucrose yield of 12.74 percent, and ranked among the best producers. In addition, because of the high tonnage of millable 
cane that it produces, it yields large quantities of sugar to the acre and compares very favorably in this aspect with most of the other canes. The next lower sucrose producers were P.O.J. 2878 and 2961, M. 275 and 341, P.R. 903, and F.C. 1017. Yet all of them yielded over 11-percent available $96^{\circ}$ sugar percent cane. P.R. 904, as evidenced by the mean yields of 40 crops, was an inferior sucrose producer as compared with other varieties, having a final sucrose concentration of less than 11 percent.

The variations in sucrose content for the same varieties in the different climatic areas shown in table 1 reveal that the varieties grown in the humid and semiarid areas are very similar having means of 12.35 - and 12.44percent sucrose, respectively. When the canes were grown in the subhumid region, however, their sucrose contents declined to a mean of 11.80 .

When the varieties were grouped according to place of origin, the mean sucrose contents were highest for the Central Aguirre (C.A.) with 13.01 percent, next, in order, for Barbados (B.) 12.62, Mayagüez (M.) 12.48, and Puerto Rico (P.R.) 12.44, and last for Java (P.O.J.), with 11.78 percent. Plantings of the C.A. varieties were limited to the irrigated semiarid southern portion of the Island. The Barbados canes were used in all three climatic zones with good results. The P.R. varieties produced generally better yields of cane in the humid than in the semiarid area, although the sucrose content remained about the same for both.

A variety having a high sucrose content does not always give high yields in tons of cane. In fact, if the varieties listed in table 1 were ranked according to their yields of tons of millable cane per acre, many of the highsucrose varieties would be low on the list. The Barbados canes B. 34-104 and 37-161, which appear tenth and eleventh in mean sucrose content for all areas (table 1), ranked as the leading varieties of tons of cane per acre in the recent variety field trials. Varieties M. 336 and M. 28, which rank high on the list for sucrose content, are relatively low in tonnage of cane per acre.

However, it is gratifying to see that the selection of new varieties has produced such changes that the leading sugar-producing varieties on the basis of hundredweights of $96^{\circ}$ available sugar per acre are higher in both tonnage and sucrose content than the earlier varieties which they are steadily replacing. The trend is toward the production of sugarcane varieties that give high yields of cane and have a high sucrose content. The sugarcane breeders are striving to give the sugarcane grower the most compact and efficient producers of sugar per acre, which means more sugar at lower cost of production.

Table 2 shows the distribution of the sugarcane varieties considered in this study according to the last varietal census conducted by the Station $(2)^{2}$. A single variety-P.O.J. 2878-occupies about two-thirds of the total

${ }^{2}$ Numbers in parentheses refer to Literature Cited, p. 34. 
acreage in sugarcane. It is grown throughout the Island. Together with B.H. 10-12 it occupies over 80 percent of the total sugarcane acreage. Both varieties are inferior in sucrose production to a number of other proven varieties such as the M. 336, and P.R.'s 907 and 902. Furthermore, they are also inferior to those three and other canes in total sugar yields, both tonnage and sucrose content considered (1).

The superior sugarcane varieties M. 336 and P.R. 907, 908, and 902 resulted from crosses between the M. 28 and P.O.J. 2878. Botanically they

TABLE 2.-Distribution of sugarcane varieties grown in Puerto Rico according to the 1949 varietal census

\begin{tabular}{l|r|r}
\hline Variety & Acreage & Percentage of total \\
\cline { 2 - 2 } & Acres & Percent \\
P.O.J. 2878 & 235,262 & 65.40 \\
B.H. $10-12$ & 54,681 & 15.20 \\
M. 275 & 14,161 & 3.93 \\
M. 28 & 11,964 & 3.33 \\
P.R. 902 & 3,691 & 1.02 \\
M. 336 & 2,196 & .61 \\
M. 317 & 1,257 & .35 \\
P.O.J. 2961 & 1,099 & .30 \\
P.R. 905 & 775 & .22 \\
B. 37-161 & 588 & .16 \\
P.R. 903 & 570 & .16 \\
M. 341 & 445 & .12 \\
P.R. 907 & 212 & .06 \\
B. $34-104$ & 196 & .05 \\
F.C. 1017 & 63 & .02 \\
P.R. 904 & 20 & .01 \\
P.R. 908 & 18 & .01 \\
Others & 32,547 & 9.05 \\
\hline
\end{tabular}

resemble both of them in many characteristics. They are all vigorous canes erect or slightly decumbent, with good to excellent stooling and tillering capacity. They grow rather rapidly, are adapted to a wide range of climatic and edaphic conditions, and have no apparent defects in milling qualities. Reference can be made to Riollano (1) for a botanical description of the M. 336 and the P.R.'s 902, 905, and 907 canes.

Any consideration of the influence of variety on the sucrose content of cane would be incomplete without a discussion of the seasonal variation encountered in the sucrose content of a specific variety. In table 3 an example is given of such seasonal variation in sucrose observed during a variety trial. In any one crop year, varieties P.R. 902, M. 28, and P.R. 905 (with the exception of the second ratoon) outyielded P.O.J. 2878 in sucrose. 
The mean difference in yield between the variety containing the most sucrose, M. 28, and that containing the least, P.O.J. 2878, was 1.05 percent. However, these varieties displayed a significant variation in sucrose content from one crop year to another. Table 3 shows that the plant-cane crop had the highest sucrose content, and the first and third ratoons the lowest. The mean variety variation in sucrose per crop year ran from a high of 13.54 for the plant cane to 11.34 for the first ratoon, a difference of 2.20. This seasonal difference was much higher than any difference en-

TABLE 3.-Seasonal variation in mean sucrose percent cane for 4 varieties of sugarcano grown at Isabela Substation, 1946-51 ${ }^{1}$

\begin{tabular}{l|c|c|c|c|c}
\hline \multirow{2}{*}{ Variety } & \multicolumn{3}{|c|}{ Mean yield in sucrose percent cane for- } & \multirow{2}{*}{$\begin{array}{c}\text { Mean of } \\
4 \text { crops }\end{array}$} \\
\cline { 2 - 3 } & $\begin{array}{c}\text { Plant cane } \\
1946-48\end{array}$ & $\begin{array}{c}\text { First ratoon } \\
1948-49\end{array}$ & $\begin{array}{c}\text { Second ratoon } \\
1949-50\end{array}$ & $\begin{array}{c}\text { Third ratoon } \\
1950-51\end{array}$ & \\
\cline { 1 - 2 } M. 28 & 13.63 & 11.68 & 12.87 & 12.02 & 12.55 \\
P.O.J. 2878 & 13.01 & 10.67 & 11.81 & 10.52 & 11.50 \\
P.R. 902 & 13.74 & 11.46 & 12.50 & 11.94 & 12.41 \\
P.R. 905 & 13.78 & 11.55 & 12.27 & 12.18 & 12.45 \\
Mean of all varieties... & 13.54 & 11.34 & 12.36 & 11.67 & 12.23 \\
\hline \hline
\end{tabular}

Least significant difference needed between varieties of same crop at-

$\begin{array}{rrrrrr}5 \text {-percent level } & 0.35 & 0.47 & 0.52 & 0.41 & 0.28 \\ 1 \text {-percent level } & .48 & .65 & .71 & .57 & .36\end{array}$

Least significant difference needed between crops at-

5 -percent level

1 -percent level
0.44

.66

${ }^{1}$ Calculated from data of P. Landrau, Jr. and G. Samuels, The response of sugarcane to fertilizers: II. The Isabela Cycle (unpublished data).

countered between varieties. The cause of this seasonal variation will be discussed in a forthcoming article in this series.

It should be remembered that comparisons between the production of varieties from one crop season to another should be evaluated with due consideration for the seasonal-variation effect. Although a high-yielding sucrose variety will tend to maintain its level when compared with other varieties in the same crop season, it may show large variations in sucrose content from one season to another.

\section{SUMMARY}

Data were obtained from 41 field experiments located throughout the Island. From the whole group of varieties tested, 20 were selected for evaluation of their sucrose production at harvesttime. The data were 
grouped according to three broad climatic areas, namely, humid, subhumid, and semiarid. Certain varieties were observed to produce better sucrose yields in a given climatic region, but in general, there were no significant differences among climatic regions for most varieties.

P.R.'s 908, 907, 902, and 905, M.'s 336 and 28, and C.A.'s 38-102 and 38-74 produced the highest sucrose yields at harvesttime. The superiority in this respect of M.'s 336 and 28, and P.R.'s 907, 902, and 905 has been definitely established. Other promising varieties need further testing. Most of these canes yield more total sugar than the standard commercial P.O.J. 2878 and B.H. 10-12 canes, which cover more than 80 percent of the total land area where sugarcane is grown in Puerto Rico.

The important bearing of seasonal variation on sucrose content of varieties is discussed. Seasonal differences in the performance of individual varieties have proved to be much greater than differences encountered between varieties in the same season.

\section{RESUMEN}

Se obtuvieron datos de 41 experimentos de campo dispersos por toda la Isla. Del grupo de variedades probadas, se seleccionaron 20 para la evaluación de su producción relativa de sacarosa al tiempo de la recolección. Los datos se agruparon de acuerdo con tres zonas climáticas amplias, a saber: Húmeda, subhúmeda y semiárida. Se observó que algunas variedades produjeron mejores rendimientos en una zona que en otra, pero en términos generales no se registraron diferencias significativas en la producción media de sacarosa de la mayoría de las variedades debido a la zona. Las variedades P.R. 908, 907, 902 y 905; M. 336 y 28 ; y C.A. 38-102 y 38-74 produjeron los más altos rendimientos de sacarosa. La superioridad en este respecto de las variedades M. 336 y 28 y P.R. 907, 902 y 905 ya ha sido definitivamente corroborada. Otras variedades prometedoras requieren aún más experimentación antes de poder evaluarlas definitivamente. La mayoría de estas variedades producen mayores rendimientos totales de azúcar que las variedades comerciales más extensamente cultivadas en la Isla, como las P.O.J. 2878 y B.H. 10-12, las cuales ocupan más del 80 porciento del área total dedicada al cultivo de la caña de azúcar. Se señala la importancia de las variaciones del clima en el contenido de sacarosa de las variedades.

\section{LITERATURE CITED}

1. Riollano, A., Nuevas variedades de caña de azúcar; Univ. of P. R., Agr. Expt. Sta., Bul. 91 1951. (A compilation of data from 28 experiments.)

2. Silva, E. and Serra, G., Census of sugarcane varieties grown in Puerto Rico for the 1949 crop; Univ. of P. R., Agr. Expt. Sta., mimeographed report, Feb. 1950. 